\title{
NAS TRAMAS DO CONTEMPORÂNEO: FETICHISMOS VISUAIS E METRÓPOLE COMUNICACIONAL
}

\author{
Andréa Vieira Zanella \\ Universidade Federal de Santa Catarina, Florianópolis, Brasil
}

O rasgo na parede azulejada expõe as entranhas da coisa morta que se revela viva. O rasgo é um atrator que captura o olhar, ouvir, sentir, enfim, mobiliza todo o corpo do observador que se estranha com a visão sensação das entranhas a mexerem com as suas próprias. Obra viva, bodycorpse que impele o corpo de quem olha "a elaborar novos sistemas perceptivos, novas sensorialidades, explorando as zonas-mortas entre o que é percebido ou, de todo modo, já visto e o que está surgindo" (Canevacci, 2008, p.31).

A lisura do azulejo esconde a infinidade inquieta e latejante de sua carne vermelha escarlate a exalar odores vários, difusos, revelados com o rasgo irregular que fixa o olho de quem olha e o provoca como múltiplo, mutável, mutante. Obra de arte que desloca e promove deslocamentos, que revela/produz uma coisa vivente e, nesse movimento, concebe/movimenta o viventecoisa, numa provocação ao dualismo coisa-pessoa/ pessoa-coisa característico da modernidade e que com as entranhas do azulejo se vê estranhado.

Obra-fetiche, obra que expõe e desnuda os fetichismos contemporâneos - donde se destacam as imagens produzidas digitalmente e que provocam a indistinção material/imaterial, corpos e mercadorias, corpos e coisas, orgânico e inorgânico - e com isso impele o expectador a se confrontar com eles; obra que provoca esse mesmo expect-ator, com todas as suas possibilidades afetivascognitivas-sensitivas, a refinar o olhar para ler/ouvir/ sentir seus apelos e a ferida que expõe a própria contemporaneidade e seus signos imagéticos.

Rasgo também é produzido pela obra de Mássimo Canevacci (2008), Fetichismos Visuais: corpos erópticos e metrópole comunicacional, que, de forma irregular, por caminhos oblíquos, direções (des)encontradas, provoca certo desassossego no leitor. A obra da artista brasileira Adriana Varejão, que integra a Tate Gallery Collection ${ }^{1}$, não está no livro, mas bem poderia, juntamente com as várias peças publicitárias, imagens de obras de arte visual, de obras arquitetônicas, fotografias de citadinos glocais, relatos de obras cinematográficas e escritos vários que compõem a matéria sobre a qual as reflexões sobre os fetichismos contemporâneos são tecidas.
Trata-se de um livro complexo que problematiza os fluxos comunicacionais produzidos nos interstícios das cidades e que as transformam em metrópole comunicacional, espaço-cenário para a produção-disseminação-apropriação de novos fetichismos que instituem, por sua vez, novos corpos, novas subjetividades. Livro que se caracteriza metodologicamente, como afirma o autor, por uma aproximação polifônica marcada por uma lógica irregular às mercadorias-fetiches contemporâneos que movem as coisas para transformá-las em sujeitos sexuados. O autor aproxima-se desses fetiches, consome-os e aparentemente se deixa consumir visando, via interpretação-destruição de seus apelos, contribuir para dissolver a reificação contemporânea.

A metrópole comunicacional e as corporeidades a ela interligadas são eleitas por Canevacci como contexto etnográfico para a pesquisa que se inspira, fundamentalmente, na Obra das Passagens, de Walter Benjamin, e o intenso debate travado entre este autor e Theodor Adorno, por meio de correspondências, sobre música, cinema (considerados facticidades comunicacionais, entre várias outras) e a reprodutibilidade técnica da obra de arte, fonte de reificação para Adorno e de liberação para Benjamin.

O conceito de facticidade se destaca porque "unifica aquele universo ('feito') de coisas-objetos-mercadorias e de corpos-edifícios-metrópoles que, em plena modernidade, se diferenciava nitidamente, enquanto na percepção reflexiva dos dois amigos já começava a se fragmentar, se atrair e reunir em constelações de movimento aparentemente lento, um movimento zero, cujos atratores estelares configuram o desenho dos fetichismos visuais" (Canevacci, 2008, p.19).

O debate entre Adorno e Benjamin, por sua vez, exprime a ruptura desses dois autores em relação a onipresença do fetichismo nas mercadorias produzidas nas fábricas, tema caro ao marxismo, que para ambos se estende às facticidades comunicacionais. Ao apresentar esse debate, capítulo que por si só justifica a leitura do livro, Canevacci problematiza a temática do fetichismo e suas condições contemporâneas, bem como a transformação das cidades em metrópoles comunicacionais.

\footnotetext{
Imagem disponível em: <http://3.bp.blogspot.com/_BXKxvhmAAJg/R9_p_TEEpCI/AAAAAAAAEyE/qrlEd4gHwqE/s400/ $\mathrm{AV},+$ Green+Tilework+in+Live+Flesh, $+2000,+$ mixed + media + on+canvas.jpg $>$.
} 
Essa transformação é anunciada por Walter Benjamin em sua análise das passages parisienses, "galerias nas quais nascem os grandes magazines, a fotografia e a plena modernidade, composta pelo consumo e pela comunicação" (Canevacci, 2008, p.278).

Nos grandes magazines as mercadorias que saem das fábricas com determinado valor adquirem muitos outros, valores esses que se caracterizam como uma trama de fetiches comunicacionais. Canevacci interpreta do seguinte modo a importância das passages: "As passages não contém dialética nem oposições dualistas, não são lugares de produção nem movem as classes: são um extraordinário espaço da mudança, que contém os traços mais significativos de uma nova modernidade, caracterizada não mais pelo trabalho, mas pelo consumo; não pelos trabalhadores, mas pelos clientes; não pela necessidade de se reproduzir, mas pelo desejo de se produzir. Com as passages, não se vive mais nas cidades e se está para entrar nas metrópoles" (Canevacci, 2008, p.278).

À problematização do conceito de fetichismo, por sua vez, o autor dedica um capítulo em que analisa o modo como este é definido pela matriz colonialista, pela teoria marxista e pela psicanálise freudiana. Ressaltando e problematizando aspectos dessas perspectivas que permanecem atuais e os que foram superados pelo movimento complexo das produções visuais contemporâneas, Canevacci destaca como suas características: "Um fetiche que soma a sacralidade do deus-objeto, o estranhamento da mercadoria-valor, a perversão do corpo sexuado. Este é o valor acrescido e o seu poder. Não é o poder de Medusa, que volta como mito petrificado em marcas, mas a potência de um fetichismo pulsante que leva a estratificar e misturar novamente o sagrado, a mercadoria, o eros dentro dos corpos de coisas. Sacralidade, estranhamento, perversão transfiguram as coisas mortas em sujeitos pulsantes. E mais ainda, acrescentam alguma coisa que antes não existia: uma empática facticidade entre sujeito e objeto" (Canevacci, 2008, p.279).
Relações entre as reflexões apresentadas por Canevacci e as temáticas que interessam à psicologia social, de certa forma presentes em todo o texto, demandam do leitor relativo esforço para evidenciá-las nos interstícios do debate em que a comunicação visual contemporânea e seus variados apelos, a produzirem alienação e reificação, são dissolvidos pela intensa análise que o autor promove a partir de algumas imagens/fetiches.

Mas essas relações são possíveis e necessárias, posto a empática facticidade entre sujeito e objeto, máxima expressão desses fechismos visuais que promovem alienação e identificação. Afinal, se concebemos a constituição do sujeito como processo de apropriação dos signos em suas significações, em um intenso, dialógico e polifônico processo de produção de sentidos, é preciso perscrutar os signos atuais, a realidade imagética que interpela a todos e que institui modos de ser consoantes com as características do contexto em que se vive.

\section{Referência Bibliográfica}

Canevacci, M. (2008). Fetichismos visuais: corpos erópticos e metrópole comunicacional. São Paulo: Ateliê Editorial.

Andréa Vieira Zanella é professora associada da Universidade Federal de Santa Catarina. Possui graduação em Psicologia pela Universidade Federal do Paraná (1986), mestrado (1992) e doutorado (1997) em Psicologia da Educação pela Pontifícia Universidade Católica de São Paulo. Realizou estudos pós-doutorais na Università Degli Studi di Roma La Sapienza, em 2009. É Bolsista de Produtividade em Pesquisa do CNPq. Email: azanella@cfh.ufsc.br

Nas tramas do contemporâneo: fetichismos visuais e metrópole comunicacional

Andréa Vieira Zanella

Recebido: 21/02/2009

Aceito: 28/03/2009 